\title{
Rapid and controlled transformation of nitrate in water and brine by stabilized iron nanoparticles
}

\author{
Zhong Xiong $\cdot$ Dongye Zhao $\cdot$ Gang Pan
}

Received: 15 October 2007 / Accepted: 27 May 2008/Published online: 2 July 2008

(C) Springer Science+Business Media B.V. 2008

\begin{abstract}
Highly reactive zero-valent iron (ZVI) nanoparticles stabilized with carboxymethyl cellulose (CMC) were tested for reduction of nitrate in fresh water and brine. Batch kinetic tests showed that the pseudo first-order rate constant $\left(k_{\text {obs }}\right)$ with the stabilized nanoparticles was five times greater than that for non-stabilized counterparts. The stabilizer not only increased the specific surface area of the nanoparticles, but also increased the reactive particle surface. The allocation between the two reduction products, $\mathrm{NH}_{4}^{+}$and $\mathrm{N}_{2}$, can be manipulated by varying the ZVI-to-nitrate molar ratio and/or applying a $\mathrm{Cu}-\mathrm{Pd}$ bimetallic catalyst. Greater CMC-to-ZVI ratios lead to faster nitrate reduction. Application of a 0.05 M HEPES buffer increased the $k_{\text {obs }}$ value by 15 times compared to that without $\mathrm{pH}$ control. Although the presence of $6 \% \mathrm{NaCl}$ decreased $k_{\text {obs }}$ by $30 \%$, $100 \%$ nitrate was transformed within $2 \mathrm{~h}$ in the saline water. The technology provides a powerful alternative for treating water with concentrated nitrate such as ion exchange brine.
\end{abstract}

Z. Xiong · D. Zhao (

Environmental Engineering Program, Department of Civil

Engineering, 238 Harbert Engineering Center,

Auburn University, Auburn, AL 36849, USA

e-mail: dzhao@eng.auburn.edu

G. Pan

Research Center for Eco-Environmental Sciences, Chinese Academy of Sciences, 18 Shuangqing Road, Beijing 100085, China
Keywords Denitrification - Ion exchange brine Nanoparticles · Nitrate $\cdot$ Reduction · Sodium carboxymethyl cellulose . Zero-valent iron (ZVI) · Water treatment

\section{Introduction}

Nitrate $\left(\mathrm{NO}_{3}{ }^{-}\right)$contamination of groundwater is a widespread environmental problem, and has been associated with agricultural runoff, leaching of nitrogen fertilizers, concentrated animal feeding operations, food processing, and industrial waste effluent discharge (Su and Puls 2004). Ingestion of nitrate in drinking water by infants can cause dangerous oxygen deficit in the blood, i.e., the "blue baby" syndrome (Fan and Steinberg 1996; Nolan et al. 1997). In order to limit the health impact of nitrate in drinking water, the U.S. EPA (1995) established a maximum contaminant level (MCL) of $10 \mathrm{mg} / \mathrm{L}$ as $\mathrm{NO}_{3}{ }^{-}-\mathrm{N}$. Although nitrate concentration in natural groundwater is generally less than $2 \mathrm{mg} / \mathrm{L}$ as $\mathrm{NO}_{3}{ }^{-}-\mathrm{N}$ (Mueller and Helsel 1996), nitrate exceeding the MCL has been detected in 10-25\% of the water-supply wells in many parts of the western, mid-western, and northeastern U.S. (Nolan et al. 1997; Smith et al. 2005).

Because of our tremendous dependence of groundwater, cost-effective remediation of nitratecontaminated groundwater has been consistently 
sought for decades. Among the most cited technologies for nitrate removal are ion-exchange (IX) (Clifford and Liu 1993a; Kim and Benjamin 2004), biological denitrification (Nuhogl et al. 2002), reverse osmosis (RO) and electrodialysis reversal (EDR) (Rautenbach et al. 1986), and chemical reduction (Peel et al. 2003). Although IX, RO, and EDR are designated as the best available technologies (BAT) by U.S. EPA, IX has been the most widely employed technology for its much lower cost and easier operation and maintenance (Clifford 1999). Since nitrate-selective resins became commercially available in the 1980s, IX process has gained growing popularity. However, application of IX has been limited by its relatively high costs of regenerant as well as brine disposal (Van der Hoek et al. 1988). Consequently, it is highly desirable to treat and reuse the spent IX brine, which is becoming more compelling as more stringent environmental regulations on brine disposal are emerging and more water utilities are forced into compliance. Similar concern also applies to RO process, where disposal of nitrate-laden rejects remains to be a costly challenge (Cox et al. 1994; Smith et al. 2005).

Compared to nitrate removal from fresh water, research on nitrate reduction in saline water has been much limited. Biological denitrification has been found effective to denitrify nitrate in seawater (Labelle et al. 2005) and in ion-exchange brine containing 1-12.5\% NaCl (Clifford and Liu 1993b; Peyton et al. 2001; Okeke et al. 2002). However, Clifford and Liu (1993b) reported a 10\% drop in denitrification rate in $0.5 \mathrm{~N} \mathrm{NaCl}$ than that in freshwater controls. Earlier, Van der Hoek et al. (1987) reported that denitrification was inhibited by the presence of high concentrations $(10-30 \mathrm{~g} / \mathrm{L})$ of $\mathrm{NaCl}$. Peyton et al. (2001) reported a specific nitrate reduction rate constant in the range from $1.20 \times 10^{-2} \mathrm{~L} /(\mathrm{h} \mathrm{mg} \mathrm{TSS})$ to $5.54 \times 10^{-3} \mathrm{~L} /$ (h mg TSS) depending on carbon sources in the presence of $12.5 \%(\mathrm{w} / \mathrm{w}) \mathrm{NaCl}$ at $\mathrm{pH} 9$. Glass and Silverstein (1999) tested the effectiveness of benchscale sequencing batch reactors (SBR) for denitrification in a wastewater containing $36 \mathrm{~g} / \mathrm{L} \mathrm{NO}_{3}{ }^{-}$at an ionic strength up to 3.0 (18\% total dissolved solids), and they observed that both nitrite and nitrate reduction rates were reduced with increasing salinity.

In recent years, a number of studies have been reported on the reduction of nitrate using zero-valent iron (ZVI) particles (Huang et al. 1998; Choe et al. 2000; Alowitz and Scherer 2002; Huang and Zhang 2004; Mishra and Farrell 2005; Sohn et al. 2006). According to these studies, nitrate is reduced by ZVI following two general pathways below (Kielemoes et al. 2000):

$$
\begin{aligned}
& 4 \mathrm{Fe}^{0}+\mathrm{NO}_{3}^{-}+7 \mathrm{H}_{2} \mathrm{O} \rightarrow \mathrm{NH}_{4}^{+}+4 \mathrm{Fe}^{2+}+10 \mathrm{OH}^{-} \\
& \Delta G^{0}=-620 \mathrm{~kJ} / \mathrm{mol} \\
& 5 \mathrm{Fe}^{0}+2 \mathrm{NO}_{3}^{-}+6 \mathrm{H}_{2} \mathrm{O} \rightarrow \mathrm{N}_{2}(\mathrm{~g})+5 \mathrm{Fe}^{2+}+12 \mathrm{OH}^{-} \\
& \Delta G^{0}=-1147 \mathrm{~kJ} / \mathrm{mol}
\end{aligned}
$$

where $\Delta G^{0}$ is the standard Gibb's free energy change. Equation 1 was invoked by Alowitz and Scherer (2002) who tested commercially available iron powders (18-35 mesh) and iron fillings (40 mesh) to reduce nitrate under controlled solution $\mathrm{pH}$ (5.5-9.0); and Eq. 2 was also proposed by Choe et al. (2000) to be the primary nitrate reduction pathway when nonstabilized (or agglomerated) ZVI nanoparticles (BET specific surface area $=31.4 \mathrm{~m}^{2} / \mathrm{g}$ ) were used in an anaerobic system under ambient conditions without $\mathrm{pH}$ control. To the best of our knowledge, there have been no reported studies on abiotic nitrate reduction by ZVI in saline water or IX brine.

Several strategies have been developed to enhance nitrate reduction by ZVI including (1) pretreatment of iron with hydrogen gas (Liou et al. 2005a) and (2) addition of metal cations such as $\mathrm{Fe}^{2+}, \mathrm{Fe}^{3+}, \mathrm{Al}^{3+}$, or $\mathrm{Cu}^{2+}$ (Huang and Zhang 2005; Liou et al. 2005b). In addition, reducing the ZVI particle size to the nanometer scale greatly increases the specific surface area, and thus, the reduction reactivity (Choe et al. 2000; Liou et al. 2005b; Yang and Lee 2005). However, non-stabilized ZVI nanoparticles, which are typically prepared following the classical borohydride reduction of ferrous or ferric ions in aqueous solution (Glavee et al. 1995), tend to agglomerate to large flocs (micrometer to millimeter scale). As a result, the unique advantage (e.g., high surface area and high reactivity) of nanoscale iron particles is diminished.

In order to prevent agglomeration of ZVI nanoparticles, He and Zhao (2005) and He et al. (2007) developed a technique for synthesizing highly stable/ dispersible ZVI nanoparticles by using an environment-friendly and low-cost starch or food-grade cellulose (known as sodium carboxymethyl cellulose, 
$\mathrm{CMC}$ ) as a stabilizer. More recently, $\mathrm{He}$ and Zhao (2007a) demonstrated that the ZVI particle size could be manipulated by applying stabilizers of various molecular weights or by tuning the stabilizer-to-ZVI molar ratio. The stabilized nanoparticles displayed both superior physical stability and much greater reactivity than their non-stabilized counterparts when used for degradation of chlorinated hydrocarbons (He et al. 2007) and perchlorate (Xiong et al. 2007).

The overall goal of this present study is to test the effectiveness of using the CMC-stabilized ZVI nanoparticles for transformation of nitrate in both fresh and saline waters or simulated IX brine. The specific objectives are to: (1) determine the rate, extent, and pathways of nitrate reduction by the stabilized ZVI nanoparticles and (2) characterize the influences of $\mathrm{ZVI}-$ to- $\mathrm{NO}_{3}{ }^{-}$molar ratio, $\mathrm{pH}$, metal catalysts, concentration of stabilizer, and salinity on the nitrate reduction rate and pathways.

\section{Experiments}

The following chemicals of analytical grade were used as received: 4-2-(Hydroxyethyl)-1-Piperazineethaneethanesulfonic acid (HEPES, $\mathrm{C}_{8} \mathrm{H}_{18} \mathrm{~N}_{2} \mathrm{O}_{4} \mathrm{~S}$ ) (Fisher Scientific, Fair Lawn, NJ, USA); 4-Morpholinoethanesulfonic acid (MES, $\mathrm{C}_{6} \mathrm{H}_{13} \mathrm{NO}_{4} \mathrm{~S} \times \mathrm{H}_{2} \mathrm{O}$ ) (Fisher); Ammonium nitrate $\left(\mathrm{NH}_{4} \mathrm{NO}_{3}\right)$ (Fisher); Ethanol $\left(\mathrm{C}_{2} \mathrm{H}_{5} \mathrm{OH}\right)$ (Fisher); Iron sulfate $\left(\mathrm{FeSO}_{4}\right.$. $7 \mathrm{H}_{2} \mathrm{O}$ ) (Acros Organics, Morris Plains, NJ, USA); Phenol $\left(\mathrm{C}_{6} \mathrm{H}_{5} \mathrm{OH}\right)$ (Fisher); Potassium hexachloropalladate $\left(\mathrm{K}_{2} \mathrm{PdCl}_{6}, 99 \%\right)$ (Acros Organics); Potassium nitrate $\left(\mathrm{KNO}_{3}\right)$ (Acros Organics); Sodium borohydride $\left(\mathrm{NaBH}_{4}\right)$ (ICN Biomedicals, Aurora, $\mathrm{OH}$ ); Sodium carboxymethyl cellulose (CMC, M.W. $=90,000, \quad$ D.S. $=0.9) \quad($ Acros Organics $)$; Sodium citrate $\left(\mathrm{Na}_{3} \mathrm{C}_{6} \mathrm{H}_{5} \mathrm{O}_{7} \cdot 2 \mathrm{H}_{2} \mathrm{O}\right)$ (Fisher); Sodium chloride $(\mathrm{NaCl})$ (Fisher); Sodium hydroxide $(\mathrm{NaOH})$ (Fisher); Sodium hyperchlorite (NaClO) (Fisher); Sodium nitrate $\left(\mathrm{NaNO}_{3}\right)$ (Fisher); Sodium nitrite $\left(\mathrm{NaNO}_{2}\right)$ (Fisher); Sodium nitroprusside $\left(\mathrm{Na}_{2} \mathrm{Fe}(\mathrm{CN})_{5}(\mathrm{NO}) \cdot 2 \mathrm{H}_{2} \mathrm{O}\right)$ (Fisher).

CMC-stabilized ZVI nanoparticles were prepared following a procedure by $\mathrm{He}$ et al. (2007). In brief, the preparation was performed in a $250-\mathrm{mL}$ flask attached to a vacuum line. Before use, deionized (DI) water was purged with purified $\mathrm{N}_{2}$ for $30 \mathrm{~min}$ to remove dissolved oxygen (DO). $\mathrm{FeSO}_{4} \cdot 7 \mathrm{H}_{2} \mathrm{O}$
(0.1 M) and CMC stock solutions (1-2\% w/w) were prepared freshly before use with $\mathrm{N}_{2}$-purged DI water. In a typical preparation, a $\mathrm{FeSO}_{4} \cdot 7 \mathrm{H}_{2} \mathrm{O}$ stock solution was added to a CMC solution to yield a desired concentration of $\mathrm{Fe}(1 \mathrm{~g} / \mathrm{L})$ and CMC $(0.2-$ $0.9 \% \mathrm{w} / \mathrm{w})$. The mixture was purged with $\mathrm{N}_{2}$ for another $30 \mathrm{~min}$ to remove $\mathrm{DO}$ and to allow formation of $\mathrm{Fe}-\mathrm{CMC}$ complexes. $\mathrm{Fe}^{2+}$ ions were then reduced to $\mathrm{Fe}^{0}$ by adding a stoichiometric amount of $\mathrm{NaBH}_{4}$ into the mixture under hand shaking. When gas (hydrogen) evolution ceased (after $\sim 15 \mathrm{~min}$ ), the ZVI nanoparticles were ready for use. In order to test the catalytic effect of palladium and/or copper, stabilized ZVI nanoparticles in select cases were loaded with $\mathrm{Pd}$ and/or $\mathrm{Cu}$ by adding $\mathrm{Pd}^{2+}$ and/or $\mathrm{Cu}^{2+}$ to the nanoparticle suspension (He and Zhao 2005). For comparison, non-stabilized ZVI particles were also prepared following the same procedure but without a stabilizer. In all cases, the nanoparticles were used or tested within $30 \mathrm{~min}$ of preparation.

In order to obtain the dynamic size distribution of the CMC-stabilized nanoparticles, dynamic light scattering (DLS) measurements were performed with a Nicomp 380 Submicron Particle Sizer (PSS, Santa Barbara, CA) at a measurement angle of $90^{\circ}$ (Internal $\mathrm{He}-\mathrm{Ne}$ laser, wavelength $633 \mathrm{~nm}$ ). Before the measurements, the $1 \mathrm{~g} / \mathrm{L}$ of CMC-stabilized ZVI nanoparticle suspension was diluted with a $0.2 \%$ CMC solution to $0.1 \mathrm{~g} / \mathrm{L}$ of $\mathrm{Fe}$. The suspension viscosity was measured with a Gilmont falling ball viscometer (Gilmont Instruments, Barrington, IL, USA) to correct the influence of viscosity on the particle mobility, and thus, the DLS measurements. The DLS measurements were performed three times (10 min each) on $1 \mathrm{~mL}$ of the diluted sample. The DLS data were processed with a standard software package CW380 to yield the number-weighted size distributions.

Batch kinetic tests of CMC-stabilized nanoparticles for nitrate reduction were conducted in $25-\mathrm{mL}$ amber glass vials capped with Teflon Mininert valves. Nitrate reduction was initiated by adding a nitrate stock solution $(2 \mathrm{~g} / \mathrm{L})$ to the freshly prepared ZVI nanoparticle suspensions to yield desired nitrate and ZVI concentrations. The dose of ZVI is represented by the $\mathrm{ZVI}$-to- $\mathrm{NO}_{3}{ }^{-}$molar ratio with a unit of mole/mole throughout this study. Dilute $(0.1 \mathrm{~N}) \mathrm{HCl}$ and/or $\mathrm{NaOH}$ were used to adjust the $\mathrm{pH}$ of the suspension, and in select cases, HEPES or MES 
buffer solution $(0.05 \mathrm{M})$ was employed to maintain a constant $\mathrm{pH}$. The vials were filled with nearly zero headspace, and the mixtures were mixed on a rotary shaker $(40 \mathrm{rpm})$ operated at room temperature $\left(21 \pm 1{ }^{\circ} \mathrm{C}\right)$. At select time intervals, $\sim 0.5 \mathrm{~mL}$ sample was taken and diluted with acidified DI water $(\mathrm{pH}=3)$ by $10-20$ times to convert the remaining ZVI nanoparticles to soluble $\mathrm{Fe}^{2+}$, and then analyzed for nitrate remaining in the aqueous phase and reduction products (e.g., nitrite and ammonium) as well. Control experiments (without the addition of ZVI nanoparticles) were carried out in parallel. All experiments were duplicated to assure data quality.

Nitrate and nitrite were analyzed using a Dionex Ion Chromatograph (DX-120) equipped with an AS14 column, an AG14 guard column, and a $100-\mu \mathrm{L}$ sample loop. A solution containing $3.5 \mathrm{mM}$ sodium carbonate and $1.0 \mathrm{mM}$ sodium bicarbonate was used as the eluent, and the eluent flow rate was set at $1.0 \mathrm{~mL} / \mathrm{min}$. The detection limit for nitrate and nitrite was $0.01 \mathrm{mg} / \mathrm{L}$ and $0.08 \mathrm{mg} / \mathrm{L}$, respectively. Ammonium was measured following the standard phenate method (Clesceri et al. 1998) with a detection limit of $0.02 \mathrm{mg} / \mathrm{L}$.

\section{Results and discussion}

\section{DLS characterization of CMC-stabilized ZVI} nanoparticles

Our prior TEM images (He et al. 2007; Xiong et al. 2007) indicated that the CMC-stabilized nanoparticles appeared as well-dispersed, discrete nanoscale particles. DLS tests in this study indicated that the mean size of $99.9 \%$ (by number) of the fresh CMC-stabilized ZVI nanoparticles (prepared at $1 \mathrm{~g} / \mathrm{L}$ and stabilized with $0.9 \% \mathrm{CMC}$ ) was $13.7 \pm 2.3 \mathrm{~nm}$ (three measurements). Based on the mean diameter of $13.7 \mathrm{~nm}$, the specific surface area was calculated to be $55.6 \mathrm{~m}^{2} / \mathrm{g}$ following the method by He and Zhao (2005).

Nitrate reduction with stabilized and nonstabilized ZVI nanoparticles

Figure 1 compares the nitrate reduction rates of nonstabilized and CMC-stabilized ZVI nanoparticles under otherwise identical conditions. In all cases, solution $\mathrm{pH}$ was confined within 7.0-7.5 with a $0.05 \mathrm{M}$ HEPES buffer solution. Stabilized

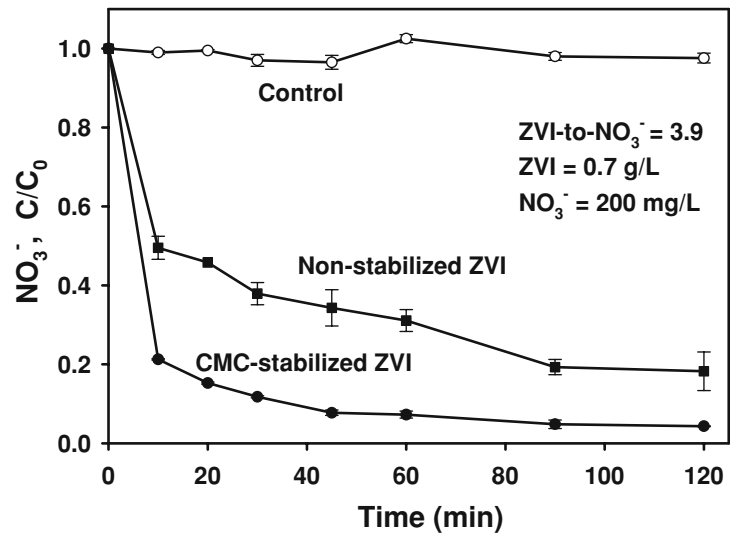

Fig. 1 Reduction of nitrate by non-stabilized ZVI and CMCstabilized ZVI nanoparticles. Initial nitrate concentration $\left(C_{0}\right)=200 \mathrm{mg} / \mathrm{L}, \mathrm{ZVI}=0.7 \mathrm{~g} / \mathrm{L}\left(\mathrm{ZVI}-\mathrm{to}_{-} \mathrm{NO}_{3}{ }^{-}=3.9\right)$, and $\mathrm{CMC}=0.63 \%$. Solution $\mathrm{pH}$ was controlled at 7.0-7.5 (initial and final) with a $0.05 \mathrm{M}$ HEPES buffer

monometallic ZVI nanoparticles displayed much improved kinetics than non-stabilized ZVI nanoparticles. In the initial $10 \mathrm{~min}$ of the reaction, the stabilized ZVI nanoparticles reduced nearly $80 \%$ of nitrate, compared to only $\sim 50 \%$ reduced by the nonstabilized ZVI. At steady state (after $\sim 90 \mathrm{~min}$ ), the stabilized ZVI nanoparticles reduced more than $96 \%$ of nitrate, compared to only $77 \%$ for the nonstabilized ZVI particles. A control test using the same concentrations of $\mathrm{Fe}^{2+}$ and $\mathrm{NO}_{3}{ }^{-}$(data not shown) indicated that there is no nitrate reduction by $\mathrm{Fe}^{2+}$ under $\mathrm{pH}$ 7.0-7.5 (0.05 M HEPES) after $24 \mathrm{~h}$.

The nitrate reduction kinetics for CMC-stabilized nanoparticles displayed a two-phase profile, i.e., a rapid initial stage $(<10 \mathrm{~min})$ followed by a gradual reduction for $2 \mathrm{~h}$. This rate profile is in accord with the notion that the surface reactivity of the ZVI nanoparticles can be diminished due to formation of passivating iron hydroxide or iron oxide layers on the ZVI surface (Huang et al. 1998). Evidently, because of the greater reactivity, the CMC-stabilized nanoparticles became exhausted more rapidly than the non-stabilized ZVI particles.

In order to quantify the reaction rate, a pseudofirst-order reaction model, Eq. 3, was used to fit the observed kinetic data (Johnson et al. 1996):

$\frac{\mathrm{d}\left[\mathrm{NO}_{3}^{-}\right]}{\mathrm{d} t}=-k_{\mathrm{SA}} a_{\mathrm{s}} \rho_{\mathrm{m}}\left[\mathrm{NO}_{3}^{-}\right]=-k_{\mathrm{obs}}\left[\mathrm{NO}_{3}^{-}\right]$

where $\left[\mathrm{NO}_{3}{ }^{-}\right]$is the nitrate concentration $(\mathrm{mg} / \mathrm{L})$ in water at time $t(\mathrm{~min}), k_{\mathrm{SA}}$ is the specific reaction rate 
constant based on the surface area of the nanoparticles $\left(\mathrm{L} /\left(\mathrm{min} \cdot \mathrm{m}^{2}\right)\right), a_{\mathrm{s}}$ is the specific surface area of the nanoparticles $\left(\mathrm{m}^{2} / \mathrm{g}\right), \rho_{\mathrm{m}}$ is the mass concentration of the nanoparticles $(\mathrm{g} / \mathrm{L})$, and $k_{\mathrm{obs}}$ is the observed pseudo-first-order rate constant $\left(\mathrm{min}^{-1}\right)$. In Eq. 3, $\left[\mathrm{NO}_{3}{ }^{-}\right], t, a_{\mathrm{s}}$, and $\rho_{\mathrm{m}}$ were measured in experiments, while $k_{\mathrm{SA}}$ and $k_{\text {obs }}$ were fitted.

Because of the labile nature of the ZVI nanoparticles and the complexity of the system, only early stage $(t=0-60 \mathrm{~min})$ data were fitted. Thus, the resultant rate constants only represent operationally defined initial rate constants, which have been commonly used to facilitate reaction rate comparison.

Table 1 gives the best-fitted model parameters. Fairly good model fittings $\left(R^{2}>0.90\right)$ were obtained for most of the reactions except in two cases: one was at a lower ZVI dose (ZVI-to- $\mathrm{NO}_{3}{ }^{-}$molar ratio $=2.5$ ), and the other was when the initial $\mathrm{pH}$ was extremely low $\left(\mathrm{pH}_{0}=2.5\right)$. This observation suggests that the pseudo-first model becomes less suitable when either ZVI supply is insufficient or when excess amounts of protons are present (note that $\mathrm{H}^{+}$accelerates $\mathrm{ZVI}$ corrosion as evidenced by the $\mathrm{pH}$ jump from the initial value of 2.5 to the final 8.6). As indicated by the observed $k_{\mathrm{obs}}$ values (\#2 and \#3 in
Table 1), the stabilized ZVI nanoparticles offered a 5.2 times greater reaction rate over the non-stabilized counterparts. In fact, the $k_{\text {obs }}$ value $\left(0.13 \mathrm{~min}^{-1}\right)$ of the CMC-stabilized ZVI nanoparticles ( $\mathrm{pH}$ 7.0-7.5 with $0.05 \mathrm{M}$ HEPES; ZVI-to- $\mathrm{NO}_{3}{ }^{-}=3.9$ ) is nine times greater than the reported $k_{\text {obs }}$ value of $0.014 \mathrm{~min}^{-1}$ for microscale ZVI particles ( $\mathrm{pH} 7.0$ with $0.1 \mathrm{M}$ HEPES; ZVI-to- $\mathrm{NO}_{3}{ }^{-}=114$ ) (Cheng et al. 1997), four times greater than the $k_{\text {obs }}$ value of $0.03 \mathrm{~min}^{-1}$ for non-stabilized 'nanoscale' ZVI particles (pH 3 with $\mathrm{HCl}$; ZVI-to- $\mathrm{NO}_{3}{ }^{-}=7.4$ ) (Yang and Lee 2005), and 43 times greater than the $k_{\text {obs }}$ value of $0.003 \mathrm{~min}^{-1}$ for surfactant-stabilized ZVI nanoparticles (pH 7.0 with $0.1 \mathrm{M} \mathrm{H}_{3} \mathrm{PO}_{4}$; ZVI-to- $\mathrm{NO}_{3}{ }^{-}=6.3$ ) (Chen et al. 2004) (Table 2). On the other hand, based on a specific surface area of $55.6 \mathrm{~m}^{2} / \mathrm{g}$ for the CMC-stabilized ZVI nanoparticles and $33.5 \mathrm{~m}^{2} / \mathrm{g}$ for non-stabilized ZVI nanoparticles reported in the literature (Wang and Zhang 1997; Choe et al. 2000; Liu et al. 2005; Yang and Lee 2005) that followed the same preparation procedure as that in this study, the $k_{\mathrm{SA}}$ was calculated to be $3.34 \times 10^{-3} \mathrm{~L} /\left(\mathrm{min} \cdot \mathrm{m}^{2}\right)$ and $1.07 \times 10^{-3} \mathrm{~L} /\left(\mathrm{min} \cdot \mathrm{m}^{2}\right)$, respectively, for CMC-stabilized and non-stabilized ZVI nanoparticles. The difference between these two $k_{\mathrm{SA}}$ values

Table 1 Model-fitted pseudo-first-order rate constants of nitrate reduction under various experimental conditions

\begin{tabular}{|c|c|c|c|c|c|c|c|c|c|}
\hline \# & $\begin{array}{l}\mathrm{ZVI} / \mathrm{NO}_{3}{ }^{-} \\
\text {molar ratio }\end{array}$ & $\begin{array}{l}\mathrm{pH} \\
\text { (initial-final) }\end{array}$ & $\begin{array}{l}\text { CMC (\%) } \\
(w / w)\end{array}$ & $\begin{array}{l}\text { Catalyst }(\% \text { of } \mathrm{Fe}) \\
(\mathrm{w} / \mathrm{w})\end{array}$ & $\begin{array}{l}\mathrm{NaCl}(\%) \\
(\mathrm{w} / \mathrm{w})\end{array}$ & $\begin{array}{l}a_{\mathrm{s}} \\
\left(\mathrm{m}^{2} / \mathrm{g}\right)\end{array}$ & $\begin{array}{l}k_{\mathrm{obs}} \\
\left(\min ^{-1}\right)\end{array}$ & $\begin{array}{l}k_{\mathrm{SA}} \\
\left(\mathrm{L} /\left(\min \cdot \mathrm{m}^{2}\right)\right)\end{array}$ & $R^{2}$ \\
\hline 1 & 2.5 & $7.0-7.5$ & 0.63 & 0 & - & 55.6 & 0.10 & $2.57 \times 10^{-3}$ & 0.74 \\
\hline 2 & 3.9 & $7.0-7.5$ & 0 & 0 & - & $33.5^{*}$ & 0.025 & $1.07 \times 10^{-3}$ & 0.94 \\
\hline 3 & 3.9 & $7.0-7.5$ & 0.63 & 0 & - & 55.6 & 0.13 & $3.34 \times 10^{-3}$ & 0.95 \\
\hline 4 & 3.9 & $7.0-7.5$ & 0.63 & $0.3 \mathrm{Pd}$ & - & - & 0.10 & - & 0.94 \\
\hline 5 & 3.9 & $7.0-7.5$ & 0.63 & $0.3 \mathrm{Cu}$ & - & - & 0.092 & - & 0.92 \\
\hline 6 & 3.9 & $7.0-7.5$ & 0.63 & $0.1 \mathrm{Pd} \& 0.4 \mathrm{Cu}$ & - & - & 0.095 & - & 0.90 \\
\hline 7 & 3.9 & $7.0-7.5$ & 0.63 & $0.4 \mathrm{Pd} \& 0.1 \mathrm{Cu}$ & - & - & 0.11 & - & 0.93 \\
\hline 8 & 3.9 & $2.5-8.6$ & 0.63 & 0 & - & 55.6 & 0.011 & $2.83 \times 10^{-4}$ & 0.74 \\
\hline 9 & 3.9 & $7.0-8.7$ & 0.63 & 0 & - & 55.6 & 0.0085 & $2.18 \times 10^{-4}$ & 0.96 \\
\hline 10 & 3.9 & $6.1-6.4$ & 0.63 & 0 & - & 55.6 & 0.41 & $1.05 \times 10^{-2}$ & 0.93 \\
\hline 11 & 5.2 & $7.0-7.5$ & 0.63 & 0 & - & 55.6 & 0.30 & $7.49 \times 0^{-3}$ & 0.99 \\
\hline 12 & 5.2 & $7.0-7.5$ & 0.63 & 0 & 1 & 55.6 & 0.29 & $7.24 \times 10^{-3}$ & 0.99 \\
\hline 13 & 5.2 & $7.0-7.5$ & 0.63 & 0 & 6 & 55.6 & 0.21 & $5.25 \times 10^{-3}$ & 0.95 \\
\hline 14 & 5.2 & $7.0-7.5$ & 0 & 0 & - & $33.5^{*}$ & 0.037 & $1.53 \times 10^{-3}$ & 0.90 \\
\hline 15 & 5.2 & $7.0-7.5$ & 0.14 & 0 & - & - & 0.20 & - & 0.98 \\
\hline 16 & 5.2 & $7.0-7.5$ & 0.36 & 0 & - & - & 0.26 & - & 0.99 \\
\hline
\end{tabular}

* From Wang and Zhang (1997)

Note: $\rho_{\mathrm{m}}=0.7 \mathrm{~g} / \mathrm{L}$ for all cases 
Table 2 Summary of nitrate reduction rate constants by various ZVI particles in the literature

\begin{tabular}{lccccccc}
\hline ZVI type & $\begin{array}{l}\mathrm{ZVI} / \mathrm{NO}_{3}{ }^{-} \\
\text {molar ratio }\end{array}$ & $\mathrm{pH}$ & $\begin{array}{l}\rho_{\mathrm{m}} \\
(\mathrm{g} / \mathrm{L})\end{array}$ & $\begin{array}{l}a_{\mathrm{s}} \\
\left(\mathrm{m}^{2} / \mathrm{g}\right)\end{array}$ & $\begin{array}{l}k_{\mathrm{obs}} \\
\left(\mathrm{min}^{-1}\right)\end{array}$ & $\begin{array}{l}k_{\mathrm{SA}} \\
\left(\mathrm{L} /\left(\mathrm{min} \cdot \mathrm{m}^{2}\right)\right)\end{array}$ & Reference \\
\hline Microscale (325 mesh) & 114.3 & 7 & 80 & - & 0.014 & - & Cheng et al. (1997) \\
Nanoscale, non-stabilized & 7.4 & 3 & 1.0 & 37.8 & 0.03 & $7.9 \times 10^{-4}$ & $\begin{array}{l}\text { Yang and Lee (2005) } \\
\text { Nanoscale, surfactant-stabilized }\end{array}$ \\
\hline
\end{tabular}

suggests that the use of the stabilizer (CMC) not only resulted in much finer nanoparticles, but also enhanced the reactivity of the particle surface. A possible reason for the increased surface reactivity is that the presence of the CMC coating prevents the formation of the passivating iron hydroxide or oxyhydroxides layer on the ZVI surface due to reaction with water. However, it is also possible that the surface of smaller nanoparticles is more reactive.

Effect of ZVI-to- $\mathrm{NO}_{3}{ }^{-}$molar ratio on nitrate reduction rate and pathways

Based on the nitrate reduction stoichiometries given in Eqs. 1 and 2, it takes a minimum ZVI-to- $\mathrm{NO}_{3}{ }^{-}$ molar ratio of 2.5 to reduce nitrate to $\mathrm{N}_{2}$ and a ZVIto- $\mathrm{NO}_{3}{ }^{-}$molar ratio of 4 to reach ammonium. Therefore, the ZVI-to- $\mathrm{NO}_{3}{ }^{-}$molar ratio can affect both nitrate reduction rates and pathways and lead to different final products $\left(\mathrm{N}_{2}\right.$ versus $\left.\mathrm{NH}_{4}{ }^{+}\right)$.

Figure 2 compares nitrate reduction rates at a ZVIto- $\mathrm{NO}_{3}{ }^{-}$molar ratio of $2.5,3.9$, and $5.2(\# 1, \# 3$, and \#11 in Table 1, respectively). Note that the ZVI-to$\mathrm{NO}_{3}{ }^{-}$molar ratio of 2.5 corresponds to the reaction stoichiometry of Eq. 2, whereas the ratio of 3.9 conforms to the pathway represented by Eq. 1. In all cases, the $\mathrm{pH}$ of the suspension was kept at 7.0-7.5 by using a $0.05 \mathrm{M}$ HEPES buffer. At the ZVI-to$\mathrm{NO}_{3}{ }^{-}$molar ratio of 2.5 , the rate profile again displayed a rapid initial reduction followed by a slower stage after $15 \mathrm{~min}$. However, the steady state was reached after $\sim 50 \mathrm{~min}$, when $\sim 83 \%$ of nitrate was transformed. At a ZVI-to- $\mathrm{NO}_{3}{ }^{-}$molar ratio of 3.9 , nearly $80 \%$ of nitrate was reduced rapidly in the first $10 \mathrm{~min}$, after which an additional $16 \%$ was rather slowly reduced by the end of experiments $(120 \mathrm{~min})$. At a ZVI-to- $\mathrm{NO}_{3}{ }^{-}$molar ratio of 5.2 (i.e., $30 \%$ above the highest possible stoichiometric quantity), $96 \%$ of nitrate was rapidly reduced within $10 \mathrm{~min}$, and nearly complete reduction was achieved within

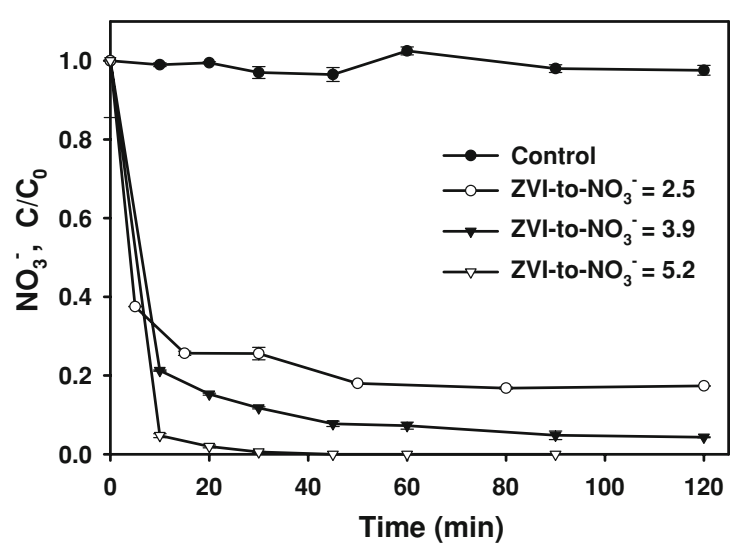

Fig. 2 Effect of $\mathrm{ZVI}$-to- $\mathrm{NO}_{3}{ }^{-}$molar ratio on nitrate reduction by CMC-stabilized ZVI nanoparticles. In all cases, $\mathrm{ZVI}=0.7 \mathrm{~g} / \mathrm{L}$, and $\mathrm{CMC}=0.63 \%$. Three initial nitrate concentrations were: $\mathrm{NO}_{3}{ }^{-}=310 \mathrm{mg} / \mathrm{L}, \quad 200 \mathrm{mg} / \mathrm{L}$, and $150 \mathrm{mg} / \mathrm{L}$. Solution $\mathrm{pH}$ was controlled at 7.0-7.5 (initial and final) with a $0.05 \mathrm{M}$ HEPES buffer

30 min. Evidently, not all the electrons from the nanoparticles were used for nitrate reduction.

The rate constant $\left(k_{\mathrm{obs}}\right)$ went up by $30 \%$ when the ZVI-to- $\mathrm{NO}_{3}{ }^{-}$molar ratio was increased from 2.5 to 3.9. However, when the $\mathrm{ZVI}$-to- $\mathrm{NO}_{3}{ }^{-}$molar ratio was further raised from 3.9 to 5.2 , the rate constant $\left(k_{\text {obs }}\right)$ increased by a factor of 2.3. The latter remarkable increase in nitrate reduction rate is, at least in part, attributed to the presence of hydrogen atom or gas resulting from the reduction of water and/or protons in the presence of excessive amounts of ZVI (i.e., greater than the maximum stoichiometric quantity of 4) as indicated by Eq. 4.

$$
\begin{aligned}
& \mathrm{Fe}^{0}+2 \mathrm{H}_{2} \mathrm{O} \rightarrow \mathrm{Fe}^{2+}+\mathrm{H}_{2}+2 \mathrm{OH}^{-} \\
& 2 \mathrm{NO}_{3}^{-}+3 \mathrm{H}_{2} \rightarrow \mathrm{N}_{2}+2 \mathrm{OH}^{-}+4 \mathrm{H}_{2} \mathrm{O} \\
& \Delta G^{0}=-1045 \mathrm{~kJ} / \mathrm{mol}
\end{aligned}
$$

Siantar et al. (1996) and Huang et al. (1998) reported that pre-treating iron particles with $\mathrm{H}_{2}$ resulted in substantial increase in nitrate reduction. A number of studies reported that hydrogen gas could 
effectively reduce nitrate to nitrogen or ammonium in the presence of a catalyst such as $\mathrm{Pd}-\mathrm{In}$ and $\mathrm{Pd}-\mathrm{Cu}$ (Lemaignen et al. 2002; Chen et al. 2003; Mikami et al. 2003). It was also reported that iron might activate sorbed $\mathrm{H}_{2}$ similar to catalytic metals such as Pd (Grittini et al. 1995; Schreier and Reinhard 1995). In our case, the transformation of nitrate can be catalyzed by the ZVI nanoparticles and/or their oxidized products (iron hydrous oxides), resulting in an additional pathway for nitrate reduction (Eq. 5).

In order to evaluate the relative weighting of the two reduction routes (i.e., Eqs. 1 and 2), coupled nitrated reduction and production of ammonium were monitored. Figure 3 shows nitrate reduction and ammonium production rates at a $\mathrm{ZVI}$-to- $\mathrm{NO}_{3}{ }^{-}$molar ratio of 2.5 or 3.9. In both cases, no nitrite $\left(\mathrm{NO}_{2}{ }^{-}\right)$ was detected, and control experiments showed that $\mathrm{CMC}$ and $\mathrm{BH}_{4}{ }^{-}$only were unable to reduce nitrate.

It is evident from Fig. 3a that the reduction of nitrate (as $\mathrm{NO}_{3}{ }^{-}-\mathrm{N}$ ) was concerted with a rise in ammonium production (as $\mathrm{NH}_{4}{ }^{+}-\mathrm{N}$ ), which again indicates rapid conversion of nitrate. Although nitric oxide and nitrous oxide were reported to be possible products for nitrate or nitrite reduction (Sorenson and Thorling 1991; Kielemoes et al. 2000) by ZVI powder or $\mathrm{Fe}^{2+}$, nitrogen gas has been generally believed to account for the incomplete mass balance of total nitrogenous species for nitrate reduction by ZVI nanoparticles (Choe et al. 2000; Chen et al. 2003; Liou et al. 2005b). In this study, the conversion of nitrate to $\mathrm{N}_{2}$ was calculated through mass balance calculations of the total nitrogen (i.e., $\mathrm{NO}_{3}{ }^{-}-\mathrm{N}+$ $\mathrm{NH}_{4}{ }^{+}-\mathrm{N}$ ) remaining in the system at a given time. Figure $3 \mathrm{a}$ shows that at steady state (after $\sim 50 \mathrm{~min}$ ), $18 \%$ of $\mathrm{NO}_{3}{ }^{-}-\mathrm{N}$ initially present in the system remained in the solution, $28 \%$ of the initial $\mathrm{NO}_{3}{ }^{-}-\mathrm{N}$ was converted to $\mathrm{NH}_{4}{ }^{+}-\mathrm{N}$ via Eq. 1 , and per mass balance calculations, $54 \%$ of $\mathrm{NO}_{3}{ }^{-}-\mathrm{N}$ was converted to $\mathrm{N}_{2}-\mathrm{N}$ via Eq. 2, i.e., $\mathrm{N}_{2}-\mathrm{N}$ accounted for two thirds $(66 \%)$ of the nitrate reduction products. Figure $3 b$ shows that when the ZVI dose was increased to the stoichiometric quantity of Eq. 1, nearly all (>98\%) nitrate was reduced within $2 \mathrm{~h}$. However, this elevated $\mathrm{ZVI}$-to- $\mathrm{NO}_{3}{ }^{-}$molar ratio seems to be more favorable to the formation of ammonium, i.e., the reaction pathway of Eq. 1. At the end of the 2-h reaction period, $\mathrm{NH}_{4}{ }^{+}-\mathrm{N}$ accounted for $62 \%$ of the initial $\mathrm{NO}_{3}{ }^{-}-\mathrm{N}$, i.e., only $36 \%$ of the reduced $\mathrm{NO}_{3}{ }^{-}-\mathrm{N}$ was converted to $\mathrm{N}_{2}-\mathrm{N}$, which is
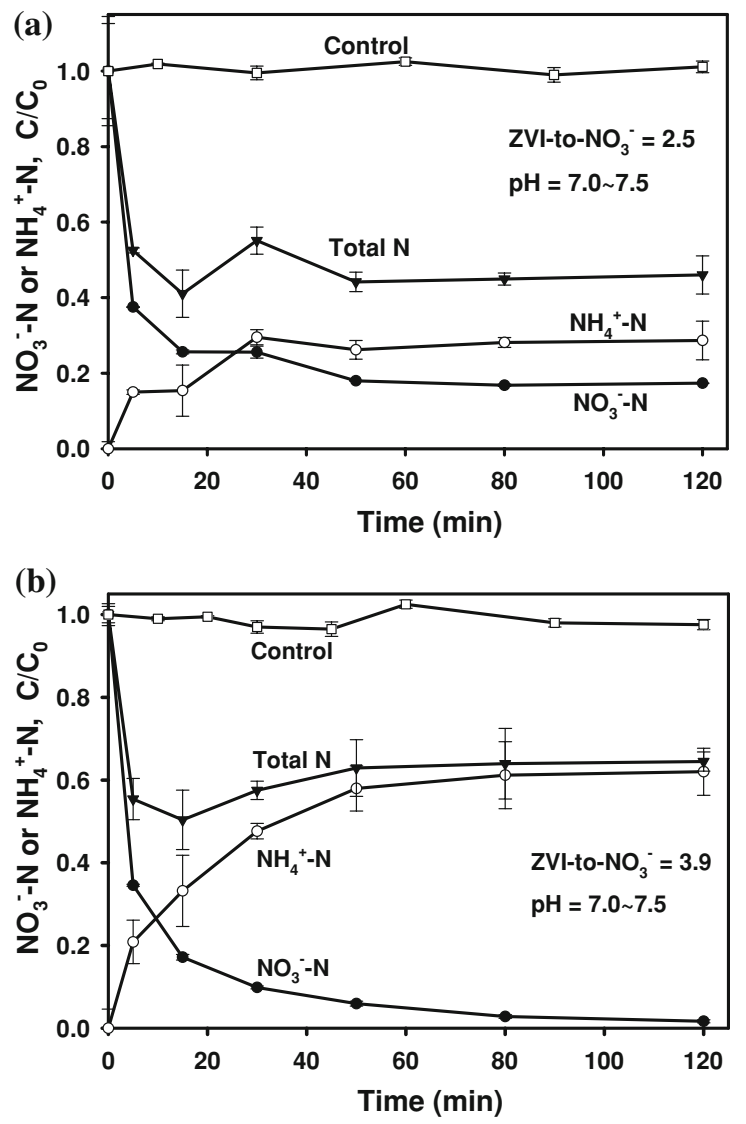

Fig. 3 Evolution of nitrate and ammonium concentrations (normalized to initial $\mathrm{NO}_{3}{ }^{-}-\mathrm{N}$ ) during nitrate reduction by CMC-stabilized ZVI nanoparticles at a $\mathrm{ZVI}-$ to- $\mathrm{NO}_{3}{ }^{-}$molar ratio of (a) $2.5\left(\mathrm{ZVI}=0.7 \mathrm{~g} / \mathrm{L} ; \mathrm{NO}_{3}{ }^{-}=310 \mathrm{mg} / \mathrm{L}\right)$ and (b) $3.9\left(\mathrm{ZVI}=0.7 \mathrm{~g} / \mathrm{L} ; \mathrm{NO}_{3}{ }^{-}=200 \mathrm{mg} / \mathrm{L}\right)$. In both cases, $\mathrm{CMC}=0.63 \%$ and solution $\mathrm{pH}$ was controlled at 7.0-7.5 (initial and final) with a $0.05 \mathrm{M}$ HEPES buffer

$30 \%$ less than that of Fig 3a. Huang et al. (1998) reported that ammonia was the sole end product when nitrate was reduced by an iron powder (size: 6-10 $\mu \mathrm{m}$ ) at a ZVI-to- $\mathrm{NO}_{3}{ }^{-}$molar ratio of 6.7. Yang and Lee (2005) reported that ammonium accounted for about $90 \%$ of the reduction products when nitrated was reduced by non-stabilized ZVI nanoparticles at a ZVI-to- $\mathrm{NO}_{3}{ }^{-}$molar ratio of $\geq 7.4$ and at acidic $\mathrm{pH}$. Chen et al. (2004) observed that at a ZVI-to- $\mathrm{NO}_{3}{ }^{-}$ molar ratio of 6.3 and $\mathrm{pH} 4-7$, microscale ZVI $(45 \mu \mathrm{m})$ powder converted $60 \%$ of nitrate after $6 \mathrm{~h}$ with ammonia being the sole end product; in contrast, a nanoscale ZVI prepared with a cationic surfactant as a dispersant was able to convert $\sim 70 \%$ of nitrate under otherwise identical conditions with both 
ammonia and $\mathrm{N}_{2}$ being the end products and ammonia accounting for $36.2-45.3 \%$ depending on $\mathrm{pH}$.

Based on the $\Delta G^{0}$ values given in Eqs. 1 and 2, nitrate reduction to $\mathrm{N}_{2}$ is thermodynamically much more favorable than toward $\mathrm{NH}_{4}{ }^{+}$. However, the fact that ammonium accounted for a relatively large fraction (especially at greater ZVI doses) of the final products indicates that the reaction pathway of Eq. 2 may bear with a greater activation energy barrier, and thus, is kinetically less favored. Alternatively, the involvement of hydrogen in nitrate reduction, which is also thermodynamically favorable (Eq. 5), appears to favor the formation of more ammonium.

Evidently, ZVI dosage not only affects the extent and rate of nitrate reduction, but also strongly impacts the nitrate reduction pathway and allocation of the final reduction products. For water or brine treatment, it is often preferred to completely remove nitrate by converting it to nitrogen gas rather than just transform it to ammonium. To this end, it is more advantageous to apply a ZVI dose in accord with the stoichiometry of Eq. 2.

\section{Effect of metal catalysts}

Coating ZVI nanoparticles with trace amounts (e.g., $0.1 \%$ of $\mathrm{Fe}$ ) of a catalytic metal (e.g., Pd) has been reported to substantially accelerate the reaction rate when used for dechlorination of chlorinated hydrocarbons (Wang and Zhang 1997; Zhang et al. 1998; $\mathrm{He}$ and Zhao 2005). Liou et al. (2005a, b) reported that coating $\mathrm{Cu}$ (at $0.5-20 \%$ of $\mathrm{Fe}$ ) on ZVI particles increased nitrate reduction rate by $2-5$ times. Horold et al. (1993) and Chen et al. (2003) observed that a bimetallic catalyst $\mathrm{Pd}-\mathrm{Cu}$ can affect the reduction pathway of nitrate by hydrogen, and a Pd-to-Cu mass ratio of 4-to-1 resulted in maximum nitrate reduction and minimum ammonium production. In order to test the effects of metal catalysts on the nitrate reduction rate and end products by stabilized ZVI nanoparticles, $\mathrm{Pd}$ and $\mathrm{Cu}$ were tested as either monometallic or bimetallic catalysts.

Figure 4 shows the nitrate reduction by the stabilized ZVI nanoparticles with or without the presence of the metal catalysts. As shown in Table 1 (\#4-\#7), the presence of the metal catalysts did not help the nitrate reduction rate. On the contrary, coating these metals on the ZVI nanoparticles reduced the rate constant $\left(k_{\text {obs }}\right)$ by $15-29 \%$. The

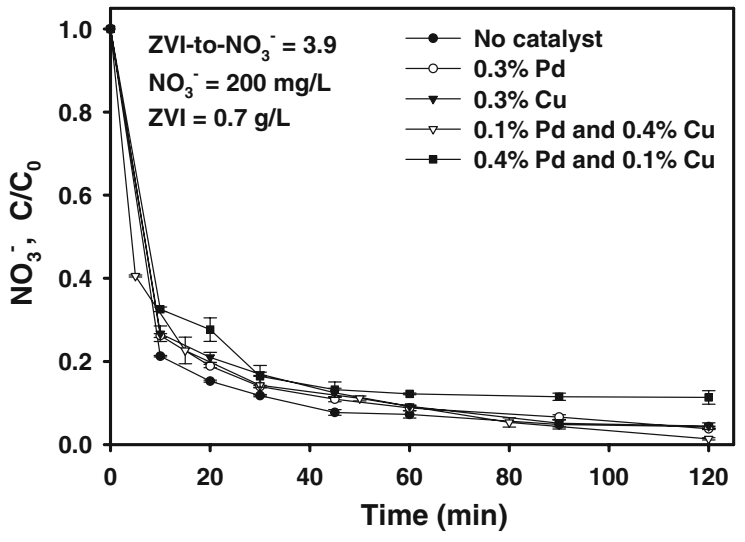

Fig. 4 Effect of metal catalysts on nitrate reduction by CMCstabilized ZVI nanoparticles at a ZVI-to- $\mathrm{NO}_{3}{ }^{-}$molar ratio of 3.9 $\left(\mathrm{ZVI}=0.7 \mathrm{~g} / \mathrm{L} ; \mathrm{NO}_{3}{ }^{-}=200 \mathrm{mg} / \mathrm{L}, \mathrm{CMC}=0.63 \%\right)$. Doses of catalysts are given as weight percentage of $\mathrm{ZVI}$ (w/w of $\mathrm{Fe}$ ). Solution $\mathrm{pH}$ was controlled at 7.0-7.5 (initial and final) with a 0.05 M HEPES buffer

metal catalysts were loaded to ZVI nanoparticles via the redox reaction,

$\mathrm{Fe}^{0}+\mathrm{Me}^{2+} \rightarrow \mathrm{Fe}^{2+}+\mathrm{Me}^{0}$

Because of the small fraction of the loaded metal catalysts relative to the amount of $\mathrm{Fe}$, the above redox reaction should not consume any significant reactivity of the ZVI nanoparticles. However, chemically, the presence of $\mathrm{Pd}$ and/or Cu may catalyze the oxidation of ZVI by water (Huang et al. 1998), as indicated in Eq. 4. Although the resultant $\mathrm{H}_{2}$ may react with nitrate in the presence of a catalyst (Horold et al. 1993), the effect of $\mathrm{Pd}$ and/or $\mathrm{Cu}$ on this side reaction diminished the overall reduction of nitrate by ZVI nanoparticles.

On the other hand, mass balance calculations on the nitrogenous species during the nitrate reduction tests indicated that in the presence of monometallic $\mathrm{Pd}$ at $0.3 \%$ of $\mathrm{Fe}$ or $\mathrm{Cu}$ at $0.3 \%$ of $\mathrm{Fe}$, the fraction of $\mathrm{NH}_{4}{ }^{+}-\mathrm{N}$ in the end products remained about the same $(62 \%)$ as in the case when no catalyst was applied. However, the presence of the bimetallic catalysts $\mathrm{Cu}-\mathrm{Pd}$ at $\mathrm{Cu}=$ $0.4 \%$ and $\mathrm{Pd}=0.1 \%$ of $\mathrm{Fe}$ or $\mathrm{Pd}-\mathrm{Cu}$ at $\mathrm{Pd}=0.4 \%$ and $\mathrm{Cu}=0.1 \%$ of $\mathrm{Fe}$ reduced the ammonium fraction to $54 \%$ and $55 \%$, respectively. Although the reaction conditions and the recipe (concentration and metal ratio) of the catalysts were not optimized, this observation indicates that the presence of metal catalysts may affect the nitrate reduction pathway, and thus, alter the allocation of ammonium and nitrogen gas in the products. 
Effect of stabilizer-to-ZVI molar ratio on reactivity of nanoparticles

As shown above, the use of CMC prevented ZVI nanoparticles from agglomeration and substantially enhanced the reactivity for nitrate reduction. Our prior work (He and Zhao 2007a, b) indicated that both size and chemical reactivity of ZVI nanoparticles could be affected by the concentration of stabilizer in relation to the ZVI concentration, i.e., the stabilizer-to-ZVI molar ratio. In order to determine the effect of the CMC-to-ZVI molar ratio on the nitrate reduction reactivity, batch kinetic tests of nitrate reduction were carried out at a fixed ZVI concentration of $0.7 \mathrm{~g} / \mathrm{L}$ and different $\mathrm{CMC}$ concentrations $(0 \%, 0.14 \%, 0.36 \%$, and $0.63 \%)$ to yield various CMC-to-ZVI molar ratios $(0,0.0012,0.0032$, and 0.0056).

Figure 5 shows the nitrate reduction by nonstabilized ZVI or ZVI nanoparticles stabilized at various CMC-to-ZVI molar ratios. Evidently, the rate (\#14-\#16 and \#11 in Table 1) and extent of nitrate reduction increased progressively as more $\mathrm{CMC}$ was applied to stabilize the nanoparticles. At a CMC-toZVI molar ratio of 0.0056 , nearly $100 \%$ of nitrate was reduced within $30 \mathrm{~min}$ compared to $<65 \%$ for the non-stabilized ZVI particles, which amounted to an 8.1 times difference in $k_{\mathrm{obs}}$ and 4.9 times difference in $k_{\mathrm{SA}}$. Our recent studies (He et al. 2007; He and Zhao 2007a) revealed that greater CMC-to-ZVI ratios resulted in finer ZVI nanoparticles. Evidently, the smaller ZVI nanoparticles not only offer greater reactive surface area, but also are more reactive. It is also evident from Fig. 5 that at equilibrium, $\sim 10 \%$ and $\sim 6 \%$ of nitrate remained intact for the nonstabilized ZVI or ZVI stabilized at a CMC-to-ZVI ratio of 0.0012 , respectively, while $100 \%$ reduction was observed when the CMC-to-ZVI ratio was higher. This observation suggests that a fraction of the ZVI electron donors in the larger ZVI particles were not available for nitrate reduction. Presumably, the more profound inactivation of ZVI in the particle cores is attributed to the formation of a thicker layer of iron oxides or iron hydroxides on the larger particles.

Effect of $\mathrm{pH}$ on nitrate reduction

Solution $\mathrm{pH}$ can affect both synthesis, and thus, the properties of the ZVI nanoparticles and the corrosion

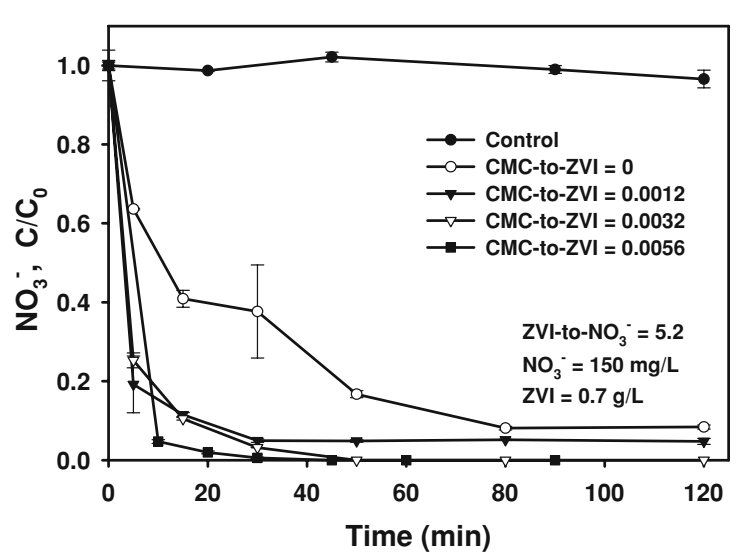

Fig. 5 Effect of CMC concentrations (CMC-to-ZVI molar ratios) on nitrate reduction by CMC-stabilized ZVI nanoparticles. Initial nitrate concentration $=150 \mathrm{mg} / \mathrm{L}$ and $\mathrm{ZVI}=$ $0.7 \mathrm{~g} / \mathrm{L}$ (ZVI-to- $\mathrm{NO}_{3}{ }^{-}=5.2$ ). Solution $\mathrm{pH}$ was controlled at 7.0-7.5 (initial and final) with a 0.05 M HEPES buffer

rate of the nanoparticles (He and Zhao 2007a). Researchers (Cheng et al. 1997; Huang et al. 1998; Zhang and Huang 2005) reported that nitrate reduction by iron powder at near-neutral $\mathrm{pH}$ was negligible in a non-buffered system, and rapid nitrate reduction was observed only when the solution was buffer at $\mathrm{pH}<7.0$.

Figure 6 shows nitrate reduction kinetics with the stabilized ZVI nanoparticles at various $\mathrm{pH}$ levels, and the $\mathrm{pH}$ evolution histories during the reactions. Table 1 (\#3, \#8-\#10) lists nitrate reduction rate constants. When the nanoparticle suspension was directly used for nitrate reduction without $\mathrm{pH}$ adjustment or addition of a buffer, the suspension $\mathrm{pH}$ experienced a rapid rise from 7.0 to 8.2 within $5 \mathrm{~min}$ of the reaction (Fig. 6b) and then a much slower increase from 8.2 to 8.7 by the end of the $120-\mathrm{min}$ test period. In this case, nitrate was reduced slowly and incompletely with an observed rate constant $k_{\text {obs }}=0.0085 \mathrm{~min}^{-1}$ and only $\sim 40 \%$ of nitrate reduced in the end. When the initial $\mathrm{pH}$ in the nanoparticle suspension was lowered to 2.5 , the observed rate constant $\left(k_{\text {obs }}\right)$ was increased to $0.011 \mathrm{~min}^{-1}$, an increase by $\sim 30 \%$. On the other hand, Fig. $6 \mathrm{~b}$ shows that the $\mathrm{pH}$ level abruptly (within $5 \mathrm{~min}$ ) rose up from 2.5 to 8.1 and then proceeded at a similar $\mathrm{pH}$ level where no $\mathrm{pH}$ adjustment was exercised. Evidently, the high concentration of extra $\mathrm{H}^{+}$ions at the lower initial $\mathrm{pH}$ was rapidly reduced to $\mathrm{H}_{2}$ by the ZVI nanoparticles 

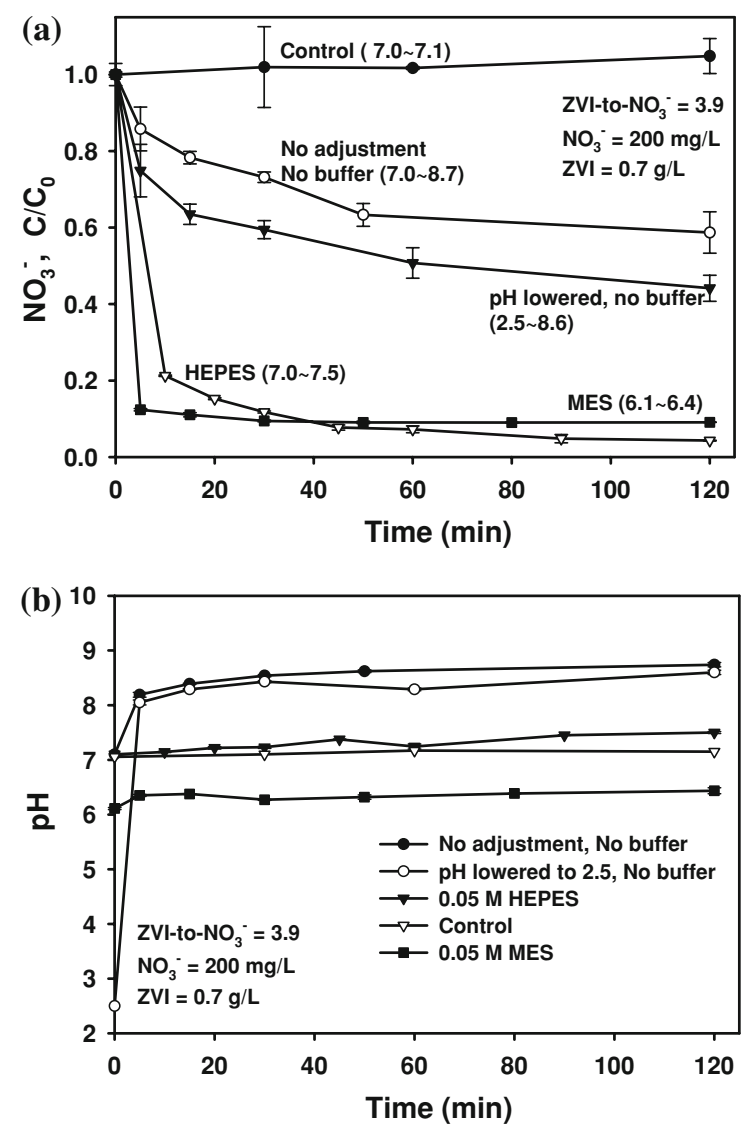

Fig. 6 (a) Effect of solution pH on nitrate reduction by CMCstabilized ZVI nanoparticles and (b) $\mathrm{pH}$ evolution during nitrate reduction. Number in the parentheses refers to initial and final $\mathrm{pH}$ values. In all cases, $\mathrm{ZVI}=0.7 \mathrm{~g} / \mathrm{L}, \mathrm{NO}_{3}{ }^{-}=$ $200 \mathrm{mg} / \mathrm{L}\left(\mathrm{ZVI}-\right.$ to- $\left.\mathrm{NO}_{3}{ }^{-}=3.9\right)$, and $\mathrm{CMC}=0.63 \%$

(Eq. 4), resulting in the sharp $\mathrm{pH}$ rebound. Based on electron balance calculations, the reduction of protons consumed $\sim 0.089 \mathrm{~g} / \mathrm{L} \mathrm{ZVI}$ (i.e., $\sim 13 \%$ of total ZVI added) and produced $1.58 \times 10^{-3} \mathrm{M} \mathrm{H}_{2}$. Liou et al. (2005a) reported that treatment of an iron powder $\left(<100\right.$ mesh) with $\mathrm{H}_{2}$ doubled the nitrate reduction rate, and due to that the presence of $\mathrm{H}_{2}$ enhanced the reactivity of the ZVI particles by removing the passive oxide layers deposited on the particle surface. In addition, it is also possible that the resultant $\mathrm{H}_{2}$ acted as an additional reducing agent (in the presence of the ZVI nanoparticles), leading to the observed enhanced nitrate reduction kinetics.

Nitrate reduction tests were also carried out with the aid of a Good's buffer (0.05 M HEPES) to hold $\mathrm{pH}$ at 7.0-7.5 (initial and final $\mathrm{pH}$ ). The $\mathrm{p} K_{\mathrm{a}}$ of HEPES is 7.45 at $20{ }^{\circ} \mathrm{C}$ (Huang and Zhang 2005). In this case, nearly $80 \%$ of nitrate was reduced in $10 \mathrm{~min}$ and $\sim 96 \%$ reduced at the end of the test $(2 \mathrm{~h})$, and the observed rate constant $\left(k_{\text {obs }}\right)$ was more than 15 times greater than that when $\mathrm{pH}$ was not controlled. For comparison, 0.05 M of MES (another Good's buffer, $\mathrm{p} K_{\mathrm{a}}=6.10$ at $25^{\circ} \mathrm{C}$ ) was also tested. In this case, $\mathrm{pH}$ was controlled in the range of 6.1-6.4 during the reaction (Fig. 6b). Compared to the case of HEPES, nitrate reduction with MES displayed an even faster initial rate $\left(k_{\mathrm{obs}}=0.41 \mathrm{~min}^{-1}\right)$, with $\sim 88 \%$ of nitrate reduced within the first $5 \mathrm{~min}$ (Fig. 6a). Again, this faster nitrate reduction at lower $\mathrm{pH}$ is attributed to the greater production of $\mathrm{H}_{2}$, which in turn refreshed the surface reactivity of the nanoparticles. Moreover, the final amount of nitrate reduced at the lower $\mathrm{pH}$ was slightly $(\sim 5 \%)$ less. This observation suggests that although lower $\mathrm{pH}$ enhanced the reaction rate, the increased conversion of the electron donor from ZVI to $\mathrm{H}_{2}$ also results in a shift of the nitrate reduction pathway. As a result, the equilibrium reduction of nitrate was lowered at a lower $\mathrm{pH}$. Note that in all cases, the ZVI nanoparticles were initially the primary electron donors although some residual $\mathrm{H}_{2}$ from the particle synthesis may also be present.

\section{Effect of salinity on nitrate reduction}

As mentioned before, IX is a BAT for nitrate removal but is held back by the costs associated with regenerant brine (typically $4-12 \%(\mathrm{w} / \mathrm{w}) \mathrm{NaCl}$ ) and brine disposal. From both economic and environmental viewpoints, it is highly desirable to treat and reuse the regenerant brine. From a practical standpoint, the advantage of the stabilized ZVI nanoparticles is best exploited when used for treating water or wastewater of highly concentrated nitrate in a confined volume such as spent nitrate-laden IX brine.

In order to test the effects of high salinity on the nitrate reduction effectiveness of the CMC-stabilized ZVI nanoparticles, batch kinetic tests were carried out in the presence of $1 \%$ and $6 \%(\mathrm{w} / \mathrm{w}) \mathrm{NaCl}$. Figure 7 shows that nitrate reduction was slightly but progressively inhibited by the high concentrations of $\mathrm{NaCl}$. Compared to the reaction without $\mathrm{NaCl}$ added, the observed rate constant (\#11-\#13 in Table 1) was reduced by $3.3 \%$ and $30 \%$, respectively, by $1 \%$ and $6 \%$ of $\mathrm{NaCl}$. He and Zhao (2007a) reported that the 


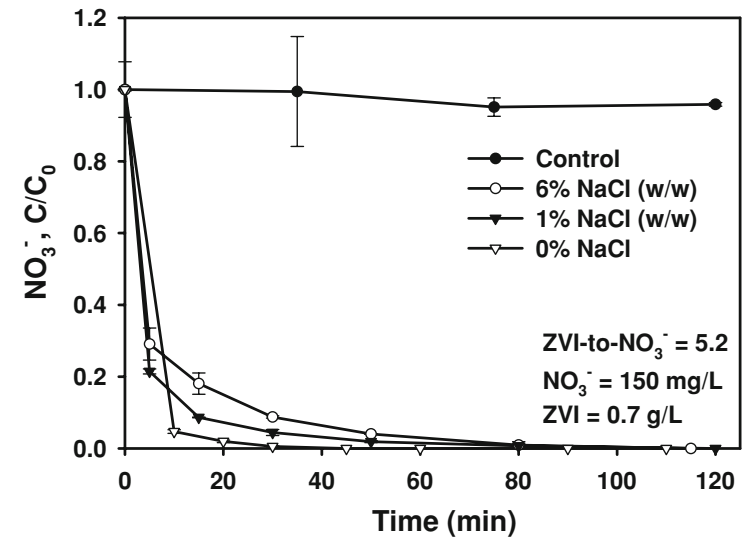

Fig. 7 Nitrate reduction by CMC-stabilized ZVI nanoparticles in the presence of various concentrations of $\mathrm{NaCl}$. Initial nitrate concentration $=150 \mathrm{mg} / \mathrm{L}, \mathrm{ZVI}=0.7 \mathrm{~g} / \mathrm{L}\left(\mathrm{ZVI}-\right.$ to $\left.-\mathrm{NO}_{3}{ }^{-}=5.2\right)$, and $\mathrm{CMC}=0.63 \%$. Solution $\mathrm{pH}$ was controlled at 7.0-7.5 (initial and final) with a $0.05 \mathrm{M}$ HEPES buffer

presence of high concentrations of cations promotes agglomeration of the CMC-stabilized nanoparticles. For instance, in the presence of $100 \mathrm{mM} \mathrm{Na}^{+}$or $0.59 \%$ of $\mathrm{NaCl}$, the primary $(63 \%)$ particle size grew to $33.7 \mathrm{~nm}$ with the remaining $37 \%$ of particles being even greater than $50 \mathrm{~nm}$. Consequently, the nitrate reduction rate was diminished due to the agglomeration and reduced specific surface area of the ZVI nanoparticles. In addition, high concentrations of chloride may also compete with nitrate for the sorption/reaction sites on the ZVI surface, thereby further discounting the reduction rate. Nonetheless, Fig. 7 showed that nearly $100 \%$ of nitrate was reduced within $90 \mathrm{~min}$ even in the presence of $6 \%$ $\mathrm{NaCl}$, suggesting that the stabilized ZVI nanoparticles remain highly effective in reducing nitrate in highly saline water or spent IX brine.

Mass balance of various nitrogenous species (data not shown) during nitrate reduction by the stabilized ZVI nanoparticles in the presence of $6 \% \mathrm{NaCl}(\mathrm{w} / \mathrm{w})$ indicated the presence of trace level $(<0.95 \mathrm{mg} / \mathrm{L})$ of nitrite-N, which were detected during the initial stage $(t<80 \mathrm{~min})$, but it disappeared thereafter. A possible reason for the nitrite presence is that nitrite is an intermediate product of nitrate reduction (Huang et al. 1998; Alowitz and Scherer 2002) and high concentrations of $\mathrm{Cl}^{-}$may slightly inhibit nitrite reduction. At the end, nitrate was transformed to ammonium (62\%) and $\mathrm{N}_{2}(38 \%)$.

As indicated by Eqs. 1 and 2, as nitrate is reduced, $\mathrm{Fe}^{0}$ is oxidized to $\mathrm{Fe}^{2+}$. The resultant ferrous ions are non-toxic and can be either reused or removed. For example, new ZVI nanoparticles can be produced in situ by reducing the existing $\mathrm{Fe}^{2+}$ ions with borohydride. Given the fairly low solubility of $\mathrm{Fe}^{2+}$ (e.g., $44 \mathrm{mg} / \mathrm{L}$ at $\mathrm{pH} 8.0$ ), it can be removed, if desired, either by slightly raising the $\mathrm{pH}$ or converting it to even less insoluble $\mathrm{Fe}^{3+}$ under ambient conditions.

\section{Conclusions}

Major conclusions from this study are summarized as follows:

(1) Highly reactive and dispersible ZVI nanoparticles can be synthesized using a low-cost and food-grade CMC as a stabilizer. DLS tests indicated that the mean size of the freshly prepared ZVI nanoparticles was $13.7 \pm 2.3 \mathrm{~nm}$ and the specific surface area was calculated to be $55.6 \mathrm{~m}^{2} / \mathrm{g}$.

(2) The stabilized ZVI nanoparticles were highly effective for nitrate reduction. At a ZVI-to$\mathrm{NO}_{3}{ }^{-}$molar ratio of 5.2 and with a $0.05 \mathrm{M}$ HEPES buffer, $150 \mathrm{mg} / \mathrm{L}$ of nitrate was nearly completely transformed within $30 \mathrm{~min}$. The observed pseudo first-order rate constant $\left(k_{\mathrm{obs}}\right)$ for nitrate reduction with the stabilized ZVI nanoparticles was more than five times greater than that for non-stabilized ZVI particles. A stabilizer (CMC) not only increased the surface area of the nanoparticles, but also resulted in greater surface reactivity.

(3) The ZVI-to- $\mathrm{NO}_{3}{ }^{-}$molar ratio not only affects nitrate reduction rate but also influences reaction pathways and final products, i.e., $\mathrm{NH}_{4}{ }^{+}$and $\mathrm{N}_{2}$. The $k_{\text {obs }}$ value was improved by about three times when the ZVI-to- $\mathrm{NO}_{3}{ }^{-}$molar ratio was increased from 2.5 to 5.2. At a ZVI-to- $\mathrm{NO}_{3}{ }^{-}$ molar ratio of $2.5, \mathrm{~N}_{2}-\mathrm{N}$ accounted for twothirds $(66 \%)$ of the nitrate reduction products, which is $30 \%$ greater than that when the ZVI-to$\mathrm{NO}_{3}{ }^{-}$molar ratio is raised to 3.9.

(4) Coating the stabilized ZVI nanoparticles with metal catalysts $(\mathrm{Pd}$ and $\mathrm{Cu})$ reduced the rate constant $\left(k_{\text {obs }}\right)$ by $15-29 \%$ due to the accelerated corrosion of ZVI by water and/or protons. However, the bimetallic catalysts $\mathrm{Cu}-\mathrm{Pd}$ at 
$\mathrm{Cu}=0.4 \%$ and $\mathrm{Pd}=0.1 \%$ of $\mathrm{Fe}$ or $\mathrm{Pd}-\mathrm{Cu}$ at $\mathrm{Pd}=0.4 \%$ and $\mathrm{Cu}=0.1 \%$ of $\mathrm{Fe}$ reduced the ammonium fraction in the final products by $8 \%$ and $7 \%$, respectively, compared to that without a catalyst.

5) The nitrate reduction rate increased progressively with the increase of the CMC-to-ZVI molar ratio. The observed rate constant $\left(k_{\text {obs }}\right)$ at a CMC-to-ZVI molar ratio of 0.0056 was 8.1 times greater than that without CMC.

(6) The nitrate reduction efficiency was strongly $\mathrm{pH}$ dependent and application of a 0.05 M HEPES buffer solution ( $\mathrm{pH} 7.0-7.5)$ increased the $k_{\mathrm{obs}}$ value by 15 times compared to that without $\mathrm{pH}$ adjustment.

(7) The presence of $6 \% \mathrm{NaCl}(\mathrm{w} / \mathrm{w})$ decreased $k_{\mathrm{obs}}$ by $30 \%$ compared to that in fresh water due to the double-layer compression effects, which leads to increased agglomeration of the ZVI nanoparticles. Nonetheless, $100 \%$ of nitrate $(150 \mathrm{mg} / \mathrm{L})$ was destroyed by $0.7 \mathrm{~g} / \mathrm{L}$ of the nanoparticles within $2 \mathrm{~h}$ in the saline water, indicating that this technology can be used to treat nitrate in both fresh water and saline water such as IX brine, membrane rejects, or industrial wastewater.

Acknowledgements The authors are grateful to Mr. Feng He and Dr. Ram Gupta for their assistance with DLS analyses. This research was partially funded by a USEPA STAR grant (GR832373), AAES Alabama Agriculture Initiative and by the USGS-Alabama Water Resources Research Institute.

\section{References}

Alowitz MJ, Scherer MM (2002) Kinetics of nitrate, nitrite, and $\mathrm{Cr}(\mathrm{VI})$ reduction by iron metal. Environ Sci Technol 36:299-306

Chen XY, Zhang Y, Chen GH (2003) Appropriate conditions or maximizing catalytic reduction efficiency of nitrate into nitrogen gas in groundwater. Water Res 37:2489-2495

Chen S-S, Hsu H-D, Li C-W (2004) A new method to produce nanoscale iron for nitrate removal. J Nanopart Res 6:639647

Cheng IF, Muftikian R, Fernando Q, Korte N (1997) Reduction of nitrate to ammonia by zero-valent iron. Chemosphere 35:2689-2695

Choe S, Chang Y-Y, Hwang K-Y, Khim J (2000) Kinetics of reductive denitrification by nanoscale zero-valent iron. Chemosphere 41:1307-1311

Clesceri LS, Greenberg AE, Eaton AD (1998) Standard methods for the examination of water and wastewater, 20th edn. American Public Health Association, Washington, DC

Clifford DA (1999) Ion exchange and inorganic adsorption. In: Lettermam RD (ed) Water quality and treatment, 5th edn. McGraw Hill, New York, pp 9.1-9.91

Clifford DA, Liu X (1993a) Ion exchange for nitrate removal. J Am Water Works Assoc 85:135-143

Clifford DA, Liu X (1993b) Biological denitrification of spent regenerant brine using a sequencing batch reactor. Water Res 27:1477-1484

Cox JL, Hallen RT, Lllga MA (1994) Thermochemical nitrate destruction. Environ Sci Technol 28:423-428

Fan AM, Steinberg VE (1996) Health implications of nitrate and nitrite in drinking water: an update on methemoglobinemia occurrence and reproductive and developmental toxicity. Regul Toxicol Pharmacol 23:35-43

Glass C, Silverstein J (1999) Denitrification of high-nitrate, high-salinity wastewater. Water Res 33:223-229

Glavee GN, Klabunde KJ, Sorensen CM, Hadjipanayis GC (1995) Chemistry of borohydride reduction of iron(II) and iron(III) ions in aqueous and nonaqueous media. Formation of nanoscale $\mathrm{Fe}, \mathrm{FeB}$, and $\mathrm{Fe}_{2} \mathrm{~B}$ powders. Inorg Chem 34:28-35

Grittini G, Malcomson M, Fernando Q, Korte N (1995) Rapid dechlorination of polychlorinated biphenyls on the surface of a $\mathrm{Pd} / \mathrm{Fe}$ bimetallic system. Environ Sci Technol 29:2898-2900

He F, Zhao D (2005) Preparation and characterization of a new class of starch-stabilized bimetallic nanoparticles for degradation of chlorinated hydrocarbons in water. Environ Sci Technol 39:3314-3320

He F, Zhao D (2007a) Manipulating the size and dispersibility of zero-valent iron nanoparticles by use of carboxymethyl cellulose stabilizers. Environ Sci Technol 41:6216-6221

He F, Zhao D (2007b) Hydrodechlorination of trichloroethene using stabilized $\mathrm{Fe} / \mathrm{Pd}$ nanoparticles: reaction mechanism and effects of stabilizer and reaction conditions. Appl Catal B-Environ (in press)

He F, Zhao D, Liu J, Roberts CB (2007) Stabilization of Fe-Pd nanoparticles with sodium carboxymethyl cellulose for enhanced transport and dechlorination of trichloroethylene in soil and groundwater. Ind Eng Chem Res 46:29-34

Horold S, Vorlop K-D, Tacke T, Sell M (1993) Development of catalysts for a selective nitrate and nitrite removal from drinking water. Catal Today 17:21-30

Huang YH, Zhang TC (2004) Effects of low pH on nitrate reduction by iron powder. Water Res 38:2631-2642

Huang YH, Zhang TC (2005) Enhancement of nitrate reduction in $\mathrm{Fe}^{0}$-packed columns by selected cations. J Environ Eng 131:603-611

Huang C-P, Wang H-W, Chiu P-C (1998) Nitrate reduction by metallic iron. Water Res 32:2257-2264

Johnson TL, Scherer MM, Tratnyek PG (1996) Kinetics of halogenated organic compound degradation by iron metal. Environ Sci Technol 30:2634-2640

Kielemoes J, De Boever P, Verstraete W (2000) Influence of denitrification on the corrosion of iron and stainless steel powder. Environ Sci Technol 34:663-671

Kim J, Benjamin MM (2004) Modeling a novel ion exchange process for arsenic and nitrate removal. Water Res 38:2053-2062 
Labelle MA, Juteau P, Jolicoeur M, Villemur R, Parent S, Comeau Y (2005) Seawater denitrification in a closed mesocosm by a submerged moving bed biofilm reactor. Water Res 39:3409-3417

Lemaignen L, Tong C, Begon V, Burch R, Chadwick D (2002) Catalytic denitrification of water with palladium-based catalysts supported on activated carbons. Catal Today 75:43-48

Liou YH, Lo SL, Lin CJ, Hu CY, Kuan WH, Weng SC (2005a) Methods for accelerating nitrate reduction using zerovalent iron at near-neutral $\mathrm{pH}$ : effects of $\mathrm{H}_{2}$-reducing pretreatment and copper deposition. Environ Sci Technol 39:9643-9648

Liou YH, Lo SL, Lin CJ, Kuan WH, Weng SC (2005b) Chemical reduction of an unbuffered nitrate solution using catalyzed and uncatalyzed nanoscale iron particles. J Hazard Mater 127:102-110

Liu Y, Majetich SA, Tilton RD, Sholl DS, Lowry GV (2005) TCE dechlorination rates, pathways, and efficiency of nanoscale iron particles with different properties. Environ Sci Technol 39:1338-1345

Mikami I, Sakamoto Y, Yoshinaga Y, Okuhara T (2003) Kinetic and adsorption studies on the hydrogenation of nitrate and nitrite in water using $\mathrm{Pd}-\mathrm{Cu}$ on active carbon support. Appl Catal 44:79-86

Mishra D, Farrell J (2005) Understanding nitrate reactions with zerovalent iron using Tafel analysis and electrochemical impedance spectroscopy. Environ Sci Technol 39:645-650

Mueller DK, Helsel DR (1996) Nutrients in the nation's waters-too much of a good thing? US Geological Survey, Reston, VA, US

Nolan BT, Ruddy BC, Hitt KJ, Helsel DR (1997) Risk of nitrate in groundwaters of the United States-a national perspective. Environ Sci Technol 31:2229-2236

Nuhogl A, Pekdemir T, Yildiz E, Keskinler B, Akay G (2002) Drinking water denitrification by a membrane bio-reactor. Water Res 36:1155-1166

Okeke BC, Giblin T, Frankenberger WT (2002) Reduction of perchlorate and nitrate by salt tolerant bacteria. Environ Pollut 118:357-363

Peel JW, Reddy KJ, Sullivan BP, Bowen JM (2003) Electrocatalytic reduction of nitrate in water. Water Res 37:2512-2519

Peyton BM, Mormile MR, Petersen JN (2001) Nitrate reduction with halomonas Campisalis: kinetics of denitrification at $\mathrm{pH} 9$ and 12.5\% NaCl. Water Res 35:4237-4242

Rautenbach R, Kopp W, Hellekes R, Teter R, Van Opbergen G (1986) Separation of nitrate from well water by membrane processes (reverse osmosis/elecrodialysis reversal). Aqua $5: 279-282$
Schreier CG, Reinhard M (1995) Catalytic hydrodehalogenation of chlorinated ethylenes using palladium and hydrogen for the treatment of contaminated water. Chemosphere 31:3475-3487

Siantar DP, Schreier CG, Chou C-S, Reinhard M (1996) Treatment of 1,2-dibromo-3-chloropropane and nitratecontaminated water with zero-valent iron or hydrogen/ palladium catalysts. Water Res 30:2315-2322

Smith RL, Buckwalter SP, Repert DA, Miller DN (2005) Small-scale, hydrogen-oxidizing-denitrifying bioreactor for treatment of nitrate-contaminated drinking water. Water Res 39:2014-2023

Sohn K, Kang SW, Ahn S, Woo M, Yang S-K (2006) Fe(0) nanoparticles for nitrate reduction: stability, reactivity, and transformation. Environ Sci Technol 40:5514-5519

Sorenson J, Thorling L (1991) Stimulation by lepidocrocite $(\gamma-\mathrm{FeOOH})$ of $\mathrm{Fe}(\mathrm{II})$-dependent nitrite reduction. Geochim Cosmochim Acta 55:1289-1294

Su C, Puls RW (2004) Nitrate reduction by zerovalent iron: effects of formate, oxalate, citrate, chloride, sulfate, borate, and phosphate. Environ Sci Technol 38:27152720

U.S. Environmental Protection Agency (1995) Drinking water regulations and health advisories. Washington, DC, USA

Van der Hoek JP, Latour PJM, Klapwijk A (1987) Denitrification with methanol in the presence of high salt concentrations and at high $\mathrm{pH}$ levels. Appl Microbiol Biotechnol 27:199-205

Van der Hoek JP, Van der Hoek WF, Klapwijk A (1988) Nitrate removal from ground water: use of a nitrate selective resin and a low concentrated regenerant. Water Air Soil Pollut 37:41-53

Wang CB, Zhang WX (1997) Synthesizing nanoscale iron particles for rapid and complete dechlorination of TCE and PCBs. Environ Sci Technol 31:2154-2156

Xiong Z, Zhao D, Pan G (2007) Rapid and complete destruction of perchlorate in water and ion-exchange brine using stabilized zero-valent iron nanoparticles. Water Res 41:3497-3505

Yang GC, Lee HL (2005) Chemical reduction of nitrate by nanosized iron: kinetics and pathways. Water Res 39:884894

Zhang TC, Huang YH (2005) Effects of selected Good's pH buffers on nitrate reduction by iron powder. J Environ Eng 131:461-470

Zhang WX, Wang CB, Lien HL (1998) Treatment of chlorinated organic contaminants with nanoscale bimetallic particles. Catal Today 40:387-395 